\title{
MOISTURE ACCUMULATION IN RENOVATED EXTERNAL WALLS
}

\author{
Jolanta Šadauskiené ${ }^{1}$, Lina Šeduikyté \\ ${ }^{I}$ Institute of Architecture and Construction of Kaunas University of Technology, \\ Tunelio Str. 60, LT - 44405 Kaunas, Lithuania \\ ${ }^{2}$ Kaunas University of Technology, Faculty of Civil Engineering and Architecture, \\ Studentų Str. 48, LT - 51367 Kaunas, Lithuania \\ E-mail:. jolanta.sadauskiene@ktu.lt; ${ }^{2}$ lina.seduikyte@ktu.lt (correspondingauthor)
}

\begin{abstract}
Multifamily apartment houses build up until 1993 have to be renovated in order to reduce energy consumption. After renovation, air tightness of buildings is increased, however, in most cases heating-ventilation systems are not changed, so they are unable to perform their functions in the sealed buildings. If adequate ventilation is not ensured, indoor environment in apartments might decrease, i.e. relative humidity might increase. If water vapour diffusion through the walls takes place during the cold season, water vapor condenses inside the envelope. The aim of this work is to determine the changes of moisture behavior of the external walls of the renovated buildings, to identify the possibility of accumulation of condensation under certain environmental conditions, to assess the risk of moisture condensation for the external envelope durability.
\end{abstract}

Keywords: moisture, water vapour diffusion, thermal insulation, durability, renovation, condensation.

\section{Introduction}

The European Union has presented a new policy for the reduction of building energy consumption (Directive 2010/31/ES). However, reduction of energy consumption of multifamily apartment houses build up until 1993 has become a big issue for the residents and the EU Member States (Risholt et al. 2013; Baek, Park 2012).

Lithuania is one of those EU member states that have Soviet "heritage". In the former Soviet Union, the heat price was low, so envelopes of residential houses and HVAC systems were designed in accordance with the current regulations (Brauers et al. 2012; Juodis et al. 2012). Consequently, the buildings of the Soviet period have still some lifetime (STR 1.12.06:2002, Malmqvist et al. 2011). However, thermal performance of envelopes of such buildings does not meet contemporary requirements after the change in the EU energy policy. Therefore, the renovation process of such buildings is relevant for the implementation of the requirements of Directive 2010/31/EC, improving living conditions and increasing lifecycle of buildings (Andaloro et al. 2010; Pikutis, Šeduikytė 2006; Morelli et al. 2012; Czako 2012; Chow et al. 2013 ).

Indoor environment conditions and building construction lifecycle depend on the volume of renovation, type and technical solutions selected for insulation and on the quality of the work.

During the renovation process, insulation of external walls, replacement of windows and doors take place. Therefore, the air tightness of multifamily apartment houses is increased. However, the experience shows that improvement of ventilation systems during the renovation process of the buildings funded from the EU structural funds is implemented in very few cases. In most cases, it is left as it was designed in the Soviet period, and therefore it is unable to carry out all functions in the airtight buildings (STR 2.09.02:2005).

If adequate ventilation is not ensured, indoor environment in apartments might decrease, i.e. relative humidity might increase. If water vapour diffusion through the walls takes place during the cold season, water vapor condenses inside the envelope. In such a way, wall moisture concentration is increasing and its durability is decreasing.

This issue is particularly relevant when External Thermal Insulation Composite Systems (ETCS) are used for the insulation of buildings. This type of structure is layered, and water vapour transmission properties are different for each layer. Therefore, during the cold season moisture condensation can take place inside the envelope or on the inner surface of the envelope. Envelope's condensed moisture leads to the increase of the heat loss of the building, appearance of defects of external finishing, i.e. reduces the external wall finish durability.

The aim of this work is to determine the changes of moisture behavior in the renovated external walls, to determine the possibility of accumulation of condensation and under certain conditions to assess the risk of condensed moisture for external wall durability.

\section{The dependence of durability of external walls on exposure to moisture}

The durability of the finishing of external walls depends on moisture behavior. The local climate has the direct impact on moisture accumulation and durability. Climatic factors are evaluated by complex climate criterion $K$, and moisture conditions of envelope $u$ are a function of climate criterion $K$ (Ramanauskas, Stankevičius 2000):

$u=f(K)=f \cdot \frac{p \cdot \varphi}{Q_{s} \cdot A_{Q}}$

where: $u$ - moisture conditions of the envelope;

$K$ - climate criterion;

$p$ - the amount of rainfall, which causes construction dampness, per year, $\mathrm{kg} / \mathrm{kg}$;

$\varphi$ - relative humidity of air, $\%$;

$A_{\theta}$ - amplitude of variation of annual outdoor air temperature, ${ }^{\circ} \mathrm{C}$;

$Q_{s}$ - the amount of heat received by the construction during the year due to solar radiation, $\mathrm{kcal} / \mathrm{m}^{2}$. 
Table 1. Schemes and physical parameters of the analyzed constructions

\begin{tabular}{|c|c|c|c|c|c|c|}
\hline Scheme of construction & Name of layer & $\begin{array}{l}\text { Material } \\
\text { layer } \\
\text { thickness } \\
d, \mathrm{~mm}\end{array}$ & $\begin{array}{l}\text { Density } \\
\rho, \mathrm{kg} / \mathrm{m}^{3}\end{array}$ & $\begin{array}{c}\text { Thermal } \\
\text { conductivity } \\
\lambda, \mathrm{W} /(\mathrm{m} \cdot \mathrm{K})\end{array}$ & $\begin{array}{c}\text { Water } \\
\text { vapour } \\
\text { resistance } \\
\text { factor } \mu\end{array}$ & $\begin{array}{r}S_{d} \\
\mathrm{~m}\end{array}$ \\
\hline 1 & 2 & 3 & 4 & 5 & 6 & 7 \\
\hline & 1. Render & 20 & 1700 & 0.9 & 6 & 0.12 \\
\hline( & $\begin{array}{l}\text { 2.Masonry of lightweight } \\
\text { concrete blocks }\end{array}$ & 240 & 400 & 0.22 & 3.6 & 0.86 \\
\hline & 3. Thin render & 10 & 1700 & 0.9 & 6 & 0.06 \\
\hline & \multicolumn{6}{|c|}{$\begin{array}{l}\text { Thermal resistance of wall } R_{T}=1.29 *\left(\mathrm{~m}^{2} \cdot \mathrm{K}\right) / \mathrm{W} \\
\text { Water vapour diffusion - equivalent air layer thickness of wall } S_{d}=1.04 \mathrm{~m} \text {. }\end{array}$} \\
\hline & 1.Paint & 0.1 & & 1 & - & 0.3 \\
\hline$\theta$ & 2. Render & 20 & 1700 & 0.9 & 6 & 0.12 \\
\hline & $\begin{array}{l}3 \text { Masonry of lightweight } \\
\text { concrete blocks }\end{array}$ & 240 & 400 & 0.22 & 3.6 & 0.86 \\
\hline & 4. Thin render & 10 & 1700 & 0.9 & 6 & 0.06 \\
\hline & 5 Paint & 0.1 & & 1 & - & 0.3 \\
\hline & \multicolumn{6}{|c|}{$\begin{array}{l}\text { Thermal resistance of wall } R_{T}=1.294 *\left(\mathrm{~m}^{2} \cdot \mathrm{K}\right) / \mathrm{W} \\
\text { Water vapour diffusion-equivalent air layer thickness of wall } S_{d}=1.64 \mathrm{~m} \text {. }\end{array}$} \\
\hline \multirow{5}{*}{ ( } & 1. Render & 20 & 1700 & 0.9 & 6 & 0.12 \\
\hline & $\begin{array}{l}\text { 2. Masonry of lightweight } \\
\text { concrete blocks }\end{array}$ & 240 & 400 & 0.22 & 3.6 & 0.86 \\
\hline & 3 Mineral wool & 100 & 140 & 0.04 & 1 & 0.1 \\
\hline & 4. Thin render & 10 & 1700 & 0.9 & 6 & 0.06 \\
\hline & \multicolumn{6}{|c|}{$\begin{array}{l}\text { Thermal resistance of wall } R_{T}=3.67 *\left(\mathrm{~m}^{2} \cdot \mathrm{K}\right) / \mathrm{W} \\
\text { Water vapour diffusion-equivalent air layer thickness of wall } S_{d}=1.14 \mathrm{~m} \text {. }\end{array}$} \\
\hline \multirow{6}{*}{$\oplus$} & 1. Render & 20 & 1700 & 0.9 & 6 & 0.12 \\
\hline & $\begin{array}{l}\text { 2. Masonry of lightweight } \\
\text { concrete blocks }\end{array}$ & 240 & 400 & 0.22 & 3.6 & 0.86 \\
\hline & 3 Mineral wool & 100 & 140 & 0.04 & 1 & 0.1 \\
\hline & 4. Thin render & 10 & 1700 & 0.9 & 6 & 0.06 \\
\hline & 5. Paint & 0.1 & - & 1 & - & 0.3 \\
\hline & \multicolumn{6}{|c|}{$\begin{array}{l}\text { Thermal resistance of wall } R_{T}=3.674 *\left(\mathrm{~m}^{2} \cdot \mathrm{K}\right) / \mathrm{W} \\
\text { Water vapour diffusion-equivalent air layer thickness of wall } S_{d}=1.44 \mathrm{~m}\end{array}$} \\
\hline \multirow{7}{*}{(} & 1.Paint & 0.1 & - & 1 & - & 0.3 \\
\hline & 2. Render & 20 & 1700 & 0.9 & 6 & 0.12 \\
\hline & $\begin{array}{l}\text { 3. Masonry of lightweight } \\
\text { concrete blocks }\end{array}$ & 240 & 400 & 0.22 & 3.6 & 0.86 \\
\hline & 4 Mineral wool & 100 & 140 & 0.04 & 1 & 0.1 \\
\hline & 5. Thin render & 10 & 1700 & 0.9 & 6 & 0.06 \\
\hline & 6. Paint & 0.1 & - & 1 & - & 0.3 \\
\hline & \multicolumn{6}{|c|}{$\begin{array}{l}\text { Thermal resistance of wall } R_{T}=3.68 *\left(\mathrm{~m}^{2} \cdot \mathrm{K}\right) / \mathrm{W} \\
\text { Water vapour diffusion-equivalent air layer thickness of wall } S_{d}=1.74 \mathrm{~m} \text {. }\end{array}$} \\
\hline
\end{tabular}

However, presented mathematical expression is evaluating only accumulation of moisture due to rainfall. Studies show that moisture can accumulate in the wall due to difficulties of water vapor movement from the inside to the outside part of the wall (Šadauskienè et al. 2009). Therefore, it can be stated that the durability of the external layer of the building envelope also depends on the condensed moisture:

$$
u=f\left(W_{\text {cond }}\right)=f(t \cdot g)
$$

where: $W_{\text {cond }}$ - volume of condensed moisture, $\mathrm{kg} / \mathrm{m}^{3}$;

$t$ - the duration of calculated process, $\mathrm{s}$;

$g$ - density of water vapour flow rate, $\mathrm{kg} / \mathrm{m}^{2} \mathrm{~s}$;
Density of the condensed moisture flow rate depends on water vapor permeability properties of the external layer.

The bigger water vapour resistance of the external layer, the lower density of condensed moisture flow rate is.

$g=\frac{\delta_{0}}{\mu} \cdot \frac{\Delta p}{\Delta d}=\delta_{0} \cdot \frac{\Delta p}{S_{d}}$

where: $\delta_{0}$ - water vapour permeability of air with respect to partial vapour pressure, $\mathrm{kg} /(\mathrm{m} \cdot \mathrm{s} \cdot \mathrm{Pa})$;

$S_{d}$ - water vapour diffusion-equivalent air layer thickness, m;

$\mu$ - water vapour resistance factor; 
$\Delta p$ - internal vapour pressure excess, $\mathrm{Pa}$;

$\Delta d$ - material layer thickness excess, $\mathrm{m}$.

The presumed amount of exploitation moisture, moisture accumulation in the envelope from rainfall and from inner condensation are taken into account, it can be expressed as follows:

$u(t)=\int_{0}^{t} K(\tau) d \tau+\int_{0}^{t} W_{\text {cond }}(\tau) d \tau$

where: $t$ - lifetime in exploitation, years;

$\tau$ - random duration, years.

$u(t)=P\{0<\tau<\mathrm{t}\}$

Climatic impact on the envelope durability is widely investigated (Abuku et al. 2009; Mlakar, Strancar 2013; Rouchier et al. 2013; Miniotaitè, Stankevičius 2003). However, the impact of condensed moisture was not evaluated. This paper analyzes the changes of moisture behavior of the external wall of a multifamily apartment house after renovation, when water vapour resistance of external layer is increased.

\section{Methodology and objectives}

The external wall of porous concrete masonry blocks, which after renovation was insulated with ETCS based on mineral wool, is analyzed in this paper. The structural scheme and physical parameters (STR 2.01.03:2003) of the analyzed wall are presented in Table 1.

Considering the annual moisture balance and the biggest content of accumulated condensed moisture $\left(\mathrm{kg} / \mathrm{m}^{2}\right)$ inside the envelope, it is possible to make comparison of moisture behaviour of different structures. Therefore, envelope moisture behaviour was calculated according to EN ISO 13788 requirements. Considering the fact that the movement of water vapour is a slow and long-term process, calculations were made according to the stationary conditions, assuming that the outside air corresponds to average January air temperature and relative humidity of Kaunas (Lithuania) (RSN No156-94).

When the evaluation of indoor microclimate is made according to STR 2.09.02:2005 requirements for residential buildings, the internal temperature may be in the range from 18 to $26{ }^{\circ} \mathrm{C}$ and relative air humidity in the range of $30-75 \%$. Typically, during the heating season, in apartments of multifamily apartment houses in Lithuania, indoor air temperature is about $18^{\circ} \mathrm{C}$, and in the apartments located on the corner of the house - even lower. Relative humidity might be different in the apartments located on the corners of the multifamily apartment house compared to the inner apartments. Indoor air parameters for the calculations are presented in Table 2.

The following values were calculated for all junctions of wall layers: temperature $\theta, \mathrm{C}^{\mathrm{o}}$, water vapour pressure at saturation $p_{\text {sat }}, \mathrm{Pa}$, water vapour pressure $p$, $\mathrm{Pa}$, relative humidity of air $\phi, \%$. These parameters characterizing moisture showed possibilities of moisture condensation and pointed out the location of condensation in the envelope.

Table 2. Indoor air parameters of the multifamily apartment house

\begin{tabular}{|c|c|c|c|}
\hline No & $\begin{array}{l}\theta_{s i}, \\
{ }^{\circ} \mathrm{C}\end{array}$ & $\phi, \%$. & Comments \\
\hline 1 & 18 & 50 & $\begin{array}{l}\text { Corresponds to the real environmental } \\
\text { conditions of inner apartment of the } \\
\text { multifamily apartment house. }\end{array}$ \\
\hline 2 & 18 & 70 & $\begin{array}{l}\text { Corresponds to the real environmental } \\
\text { conditions of the apartments located } \\
\text { on the corners of the multifamily } \\
\text { apartment house. }\end{array}$ \\
\hline 3 & 22 & 50 & Must comply with HN 42: 1999 \\
\hline 4 & 22 & 70 & $\begin{array}{l}\text { Must comply with HN 42: } 1999 \text {, } \\
\text { however with increased relative } \\
\text { humidity. }\end{array}$ \\
\hline
\end{tabular}

\section{Results}

Fig. 1 and 2 present the calculation results of moisture behavior of the apartments located on the corners of the multifamily apartment house, when the real climatic conditions were: the indoor air temperature $18^{\circ} \mathrm{C}$ and relative humidity $70 \%$. The results show that during the heating season there is a possibility for condensation at junction of masonry blocks and thin plaster layers in not renovated walls. After insulation of such walls with ETICS based on mineral wool there is a possibility for condensation at junction of insulation and thin plaster layer.

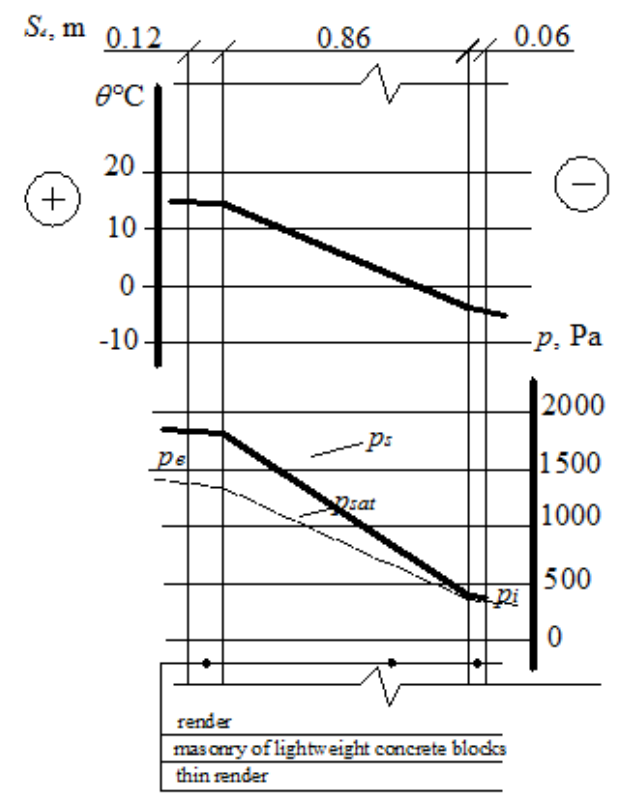

Fig. 1. Moisture behavior scheme of the not renovated exterior wall. 


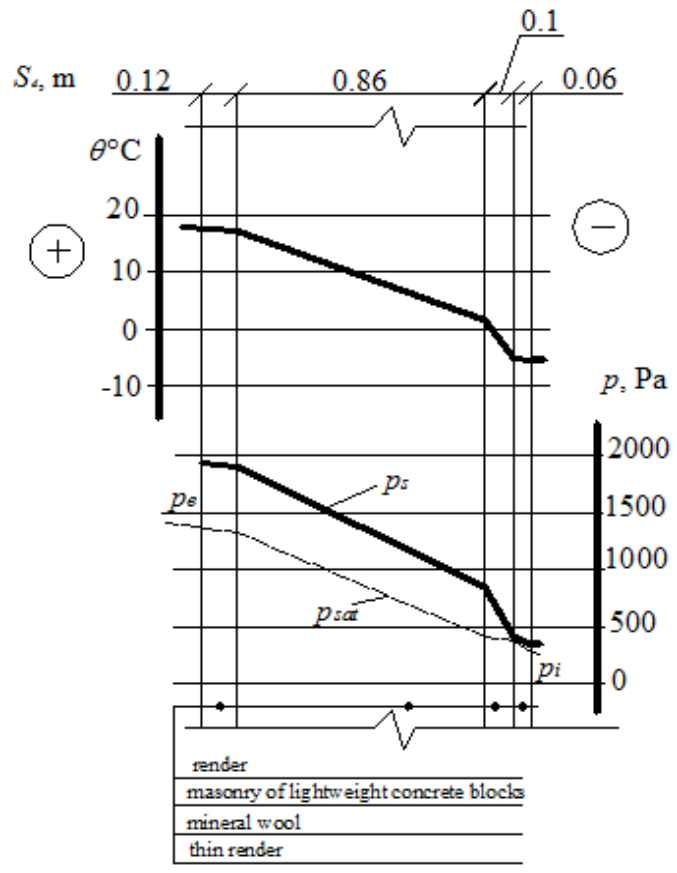

Fig. 2. Moisture behavior scheme of the renovated exterior wall.

Differences of moisture movement were observed in the analyzed wall constructions (Fig. 3), because different layers have different water vapour permeability properties. In the case of not renovated walls, water vapour permeability properties of the layers are similar, that is why variation of air relative humidity is within the range of $20 \%$.

In the case of renovated wall (Fig. 3.), relative humidity decreases (up to 39\%) until the thermal insulation layer. Then it rises rapidly and at the junction of mineral wool and external render reaches $92 \%$. This is influenced by the water vapour permeability, as for the mineral wool it is very high and for external render it is very low.

Results presented in Fig. 4 show that water vapour permeability properties of the external layers are very important for moisture accumulation in the envelope. If water vapour resistance of the external layer is increased, possibilities of condensation inside the envelope increase as well.

The analysis of the impact of indoor microclimate on moisture behavior of the wall shows (Fig. 5), that indoor air conditions determine the intensity of moisture accumulation. Relative humidity of air plays an important role in this process. If relative humidity of the air increases, moisture accumulates faster. However, additional moisture factors that appear after increase of water vapour resistance of the external layer have bigger influence on the appearance of condensation inside the envelope.

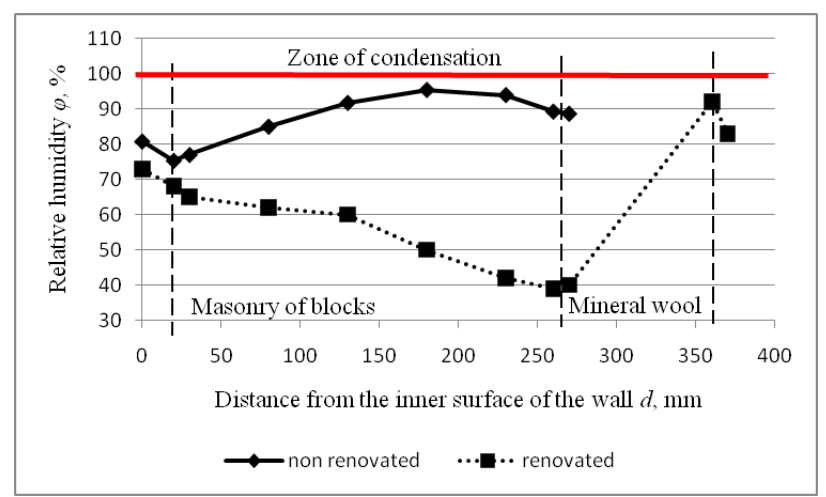

Fig. 3. Distribution of relative humidity in the layers of the wall ( 1 and 3 scheme of wall construction) when the temperature in the rooms is $18^{\circ} \mathrm{C}$, relative humidity of air $70 \%$.

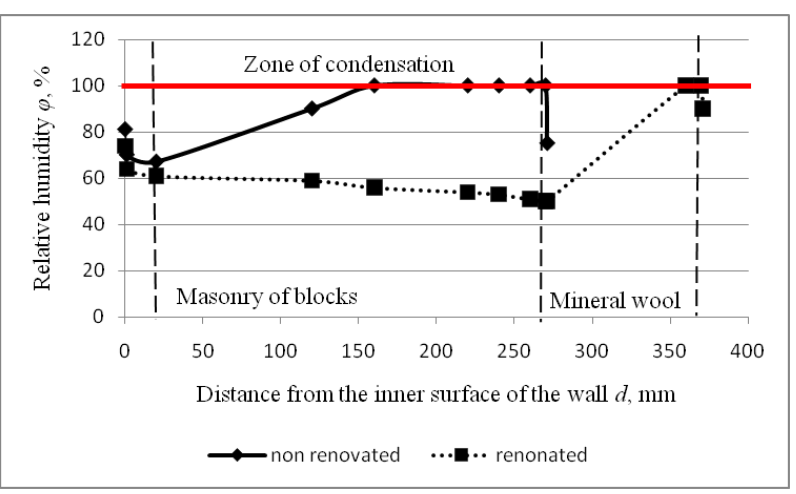

Fig. 4. Distribution of relative humidity in the layers of the wall with the painted external surface (2 and 5 scheme of wall construction) when the temperature in the rooms is $18^{\circ} \mathrm{C}$, relative humidity of air $70 \%$.

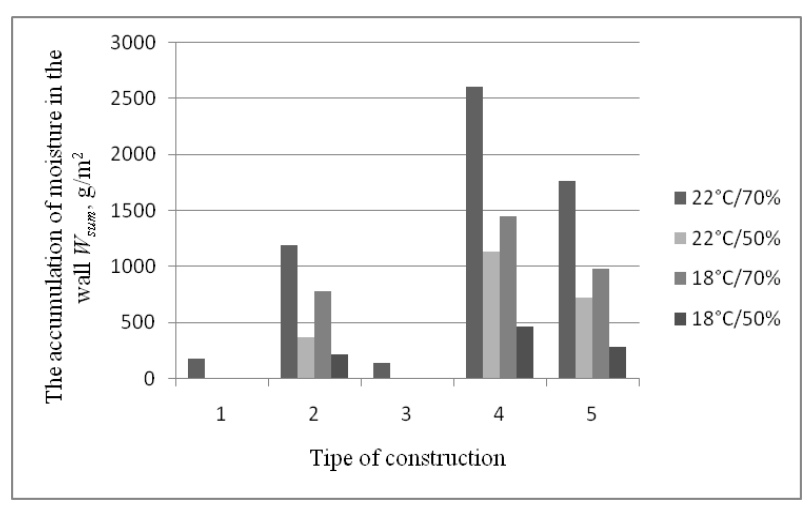

Fig. 5. Total amount of moisture that is able to accumulate during the process of condensation.

\section{Discussion}

Moisture behavior of the external wall of the multifamily apartment house after insulation with ETICS has changed, because indoor microclimate conditions of such houses changed as well. Relative humidity increased because of bad ventilation. Despite the fact that the external layer of ETICS is influenced by the aggressive climatic factors, it is also influenced by water vapor migration from room towards outdoors. 
Results presented in this paper show that incompatibility of water vapor permeability properties of the envelope layers influence possibilities of moisture accumulation. Water vapor permeability of the external paint layer is low compared with the mineral wool, so the paint layer can become a barrier for water vapor diffusion and create conditions for moisture accumulation in the wall during the cold season. Moisture can accumulate under the paint layer and be a destructive factor for the junction plane of the thin render and paint.

Accumulation of moisture inside the wall and its impact on durability depends on local climate. Unlike Western Europe, where winters are mild, the climate in the Baltic region is colder, more intensive. Thaws followed by cold weather are frequent during the cold season. This negatively affects the external finishing layer of ETICS, which stores condensed moisture. Water, freezing in pairs of thin render, will expand by destroying this layer. Intensive destruction of finishing will occur after cyclical freeze-thaw process.

Fluctuation of moisture and temperature negatively affects mineral wool. Moisture increases thermal conductivity of insulation materials; therefore effectiveness of thermal insulation layer decreases. During exploitation, mineral wool plates are in unstable humid environment, and more or less often can get wet or overdry. Repeated and different wetting or overdrying of mineral wool destroys fibers. Calcium silicates formed on the surface can drop out, and fresh opened fiber surfaces melt. This causes deformations and softening of the material.

During the design process of building structures with layers, the layers should be arranged so that the water vapour permeability increase toward the outside part, i.e. the external layer of the wall must be with highest water vapour permeability.

\section{Conclusions}

During renovation of multifamily apartment houses, when heating and ventilation systems are not modernized, indoor microclimate of apartments is changed as well as moisture behavior of the external walls.

In the Baltic region during the heating season, there is a possibility for condensation at junction of masonry blocks and thin plaster layers in not renovated walls and after renovation of such walls with ETICS based on mineral wool there is a possibility for condensation at junction of insulation and thin plaster layer.

The durability of external walls insulated with mineral wool and finished with painted thin render depends on water vapour permeability of the external layers and the combination of these values in different layers, which allows the smallest internal and external moisture accumulation in the wall structure.

\section{References}

Abuku, M.; Janssen, H.; Roels, S., 2009. Impact of wind-driven rain on historic brick wall buildings in a moderately cold and humid climate: Numerical analyses of mould growth risk, indoor climate and energy consumption. Energy and Buildings, 41(1), pp.101-110. http://dx.doi.org/10.1016/j.enbuild.2008.07.011

Andaloro, A. P. F.; Salomone, R.; Ioppolo, G.; Andaloro, L., 2010. Energy certification of buildings: A comparative analysis of progress towards implementation in European countries. Energy Policy, 38, pp.5840-5866. http://dx.doi.org/10.1016/j.enpol.2010.05.039

Baek, C. H.; Park, S. H., 2012. Changes in renovation policies in the era of sustainability. Energy and Buildings, 47, pp. 485-496. http://dx.doi.org/10.1016/j.enbuild.2011.12.028

Brauers, W. K .M.; Kracka, M.; Zavadskas, K., 2012. Lithuanian case study of masonry buildings from the Soviet period. Journal of Civil Engineering and Management, 18(3), pp. 444-456. http://dx.doi.org/10.3846/13923730.2012.700944

Chow, D. H. C.; Li, Z.; Darkwa, J., 2013. The effectiveness of retrofitting existing public buildings in face of future climate change in the hot summer cold winter region of China. Energy and Buildings, 57, pp.176-186. http://dx.doi.org/10.1016/j.enbuild.2012.11.012

Czako, V., 2012. Evoliution of Hungarian residential energy efficiency support programmes: road to and operation under the Green Investmen Scheme. Energy efficiency, 5(2), pp.163-178.

Directive 2010/31/EC of the European Parliament and of the Council of 19 May 2010 on the energy performance of buildings (recast), Brussels, [cited 26 June 2012]. Available at: http://eur-lex.europa.eu/LexUriServ/LexUriServ.do?uri= OJ:L:2010:153:0013:0035:EN:PDF

HN 42:2004. Microclimate of Residential and Public Buildings, Vilnius, Ministry of Environment of Republic of Lithuania. 2004. (in Lithuanian).

Juodis, E.; Jaraminiene, E.; Dudkiewicz, E., 2009. Inherent variability of heat consumption in residential buildings. Energy and Buildings, 41(11), pp.1188-1194.

LST EN ISO 13788:2002. Hygrothermal performance of building components and building elements - Internal surface temperature to avoid critical surface humidity and interstitial condensation - Calculation methods, Brussels. 36 p.

LST EN 13500:2004. Thermal Insulation Products for Buildings External Thermal Insulation Composite Systems (ETICS) Based on Mineral Wool - Specification. Brussels. 74 p.

Malmqvist, T.; Glaumann, M.; Scarpellini, S.; Zabalza, I.; Aranda, A.; Liera, E.; Diaz, S., 2011. Life cicle assessment in buildings: The ENSLIC simplified method and guidelines. Energy, 36, pp.1900-1907. http://dx.doi.org/10.1016/j.energy.2010.03.026

Miniotaite R.; Stankevičius, V., 2003. The Durability of Paints on Sand-lime Brick Walls Considering Water Sorption and Vapour Permeability in a Two-layer System. Journal of Civil Engineering and Management, 9(2), pp.110-114. http://dx.doi.org/10.1080/13923730.2003.10531313

Mlakar, J.; Strancar, J., 2013. Temperature and humidity profiles in passive-house building blocks. Building and Environment, 60, pp. 185-193.

http://dx.doi.org/10.1016/j.buildenv.2012.11.018 
Morelli, M.; Ronby, L.; Mikkelsen, S. E.; Minzari, M. G.; Kidemoes, T.; Tommerup, H. M., 2012. Energy retrofitting of a typical old Danish multi-family building to a "nearlyzero" energy building based on experiences from a test apartment. Energy and Buildings, 54, pp. 395-406.

http://dx.doi.org/10.1016/j.enbuild.2012.07.046

Pikutis, R.; Šeduikyte, L., 2006. Estimation of effectiveness of renovation work in Lithuanian Schools. Journal of Civil Engineering and Management, 12(2), pp. 163-168.

Ramanauskas, J.; Stankevičius, V., 2000. Weather durability of thermal insulation system in external wall. Monography, Kaunas, Technologija. $142 \mathrm{p}$.

Risholt, B.; Time, B.; Hestnes, A.G., 2013. Sustainability assessment of nearly zero energy renovation of dwellings based on energy, economy and home quality indicators. Energy and Buildings, 60, pp. 217-224. http://dx.doi.org/10.1016/j.enbuild.2012.12.017

Rouchier, S.; Woloszyn, M.; Foray, G.; Roux, J. J., 2013. Influence of concrete fracture on the rain infiltration and thermal performance of building facades. International Journal of Heat and Mass Transfer, 61, pp.340-352.

http://dx.doi.org/10.1016/j.ijheatmasstransfer.2013.02.013

RSN Nr.156-94. Building Climatology. Vilnius. 1995: 136 p. (in Lithuanian).

STR 1.12.06:2002. Building usage and lifetime. Construction technical regulation. Lithuania, 2002. (in Lithuanian).

STR 2.01.0:2003. Thermal technical declared and project values of building materials and products. Lithuania, 2003. (in Lithuanian).

STR 2.09.02:2005. Heating ventilation and air conditioning. Lithuania, 2005. (in Lithuanian).

Šadauskienė, J.; Stankevičius, V.; Bliūdžius, R.; Gailius, A., 2009. The impact of the exterior painted thin-layer render's water vapour and liquid water permeability on the moisture state of the wall insulating system. Construction and Building Materials, 23, pp.2788-2794.

http://dx.doi.org/10.1016/j.conbuildmat.2009.03.010 